\title{
GOOD GOVERNANCE AND NATURAL RESOURCE CURSE; WHICH HYPOTHESIS IS PREVAILING IN ASEAN ECONOMIES?
}

\author{
Deden Dinar Iskandar ${ }^{1}$, Adhevyo Reza ${ }^{2}$, Robertus Mulyo Hendarto \\ ${ }^{1}$ Diponegoro University, deden_dinar@live.undip.ac.id; \\ ${ }^{2}$ Diponegoro University, adhevyoreza@gmail.com; \\ 32Diponegoro University, mulyohendarto@yahoo.com.
}

\begin{abstract}
This study aims to find the relevance of the natural resource curse and good governance hypothesis in ASEAN economies post-financial crises 1998. Employing Generalized Method of Moments (GMM), this study finds that good governance practices (Control of Corruption, Political Stability, and Voice and Accountability) play a role in the ASEAN economies after the great financial crisis. On the other hand, the observation of the natural resource curse hypothesis in ASEAN countries returns mixed results. This study finds that dependence on the natural resource by itself does not affect GDP. However, the natural resource curse occurs when countries with bad governance (low Control of Corruption) depend on agriculture resources. On the other hand, the natural resource becomes a blessing when the countries that rely on agriculture resources are supported with good governance practices in terms of strong Government Effectiveness, Political Stability, and Voice and Accountability. This paper highlights the importance of observing the natural resource and good governance in interaction instead of in isolation and the relevance of disaggregating the indicators of good governance as well as natural resources.
\end{abstract}

Keywords: ASEAN economies, control of corruption, good governance, natural resource curse, Worldwide Governance Indicators (WGI)

JEL Classification: O11, O13, O43, O51, P28

\begin{abstract}
Abstrak
Studi ini bertujuan untuk menemukan relevansi kutukan sumber daya alam dan hipotesis tata kelola yang baik di ekonomi ASEAN pasca krisis keuangan 1998. Menggunakan Metode Generalized of Moments (GMM), studi ini menemukan bahwa praktik tata kelola yang baik (Control of Corruption, Political Stability, dan Voice and Accountability) memainkan peran penting dalam perekonomian ASEAN. Dengan demikian, hipotesis yang menyatakan bahwa praktik tata kelola yang baik akan meningkatkan pembangunan ekonomi terkonfirmasi. Di sisi lain, pengamatan terhadap hipotesis kutukan sumber daya alam di negara-negara ASEAN memberikan hasil yang beragam. Hipotesis ini menyatakan bahwa kelimpahan sumber daya alam bisa dikaitkan dengan kinerja ekonomi yang lebih rendah. Studi ini menemukan bahwa ketergantungan pada sumber daya alam tidak secara langsung mempengaruhi PDB. Namun, kutukan sumber daya alam bisa terjadi ketika negara-negara dengan tata kelola yang buruk (Control of Corruption yang rendah) terlalu bergantung pada sumber daya pertanian. Di sisi lain, sumber daya alam menjadi berkah ketika negara-negara yang mengandalkan sumber daya pertanian didukung dengan praktik tata kelola yang baik dalam hal Governance Effectiveness, Political Stability, serta Voice and Accountability. Dengan demikian, pengaruh sumber daya alam terhadap pembangunan ekonomi tergantung pada kualitas tata kelola pemerintahan dalam negara yang bersangkutan. Tulisan ini menyoroti pentingnya mengamati sumber daya alam dan tata kelola secara bersama-sama, dan bukan secara terpisah, serta pentingnya menggunakan indikatorindikator tata kelola yang baik serta sumber daya alam secara lebih mendetail.
\end{abstract}

Kata Kunci: Perekonomian ASEAN, pengendalian korupsi, tata kelola pemerintahan, kutukan sumber daya alam, Worldwide Governance Indicators (WGI)

Klasifikasi JEL: O11, O13, O43, O51, P28 


\section{INTRODUCTION}

ASEAN (Association of Southeast Asian Nation) currently consists of 11 country members, including Indonesia, Malaysia, Philippines, Singapore, Thailand, Vietnam, Myanmar, Cambodia, Laos, Brunei Darussalam, and East Timor. After the great economic crisis in 1998, ASEAN countries can make a fast recovery in term of economic growth. At the beginning of 1998, ASEAN countries have an average growth rate of $-1.09 \%$ but five years later the average of their economic growth reaches $6.54 \%$. To provide the comparison, the average ASEAN economic growth is greater than the EU and Latin America with a growth of $1.52 \%$ and $2.82 \%$ respectively, and above the average of world economic growth at $2.90 \%$.

Indonesia is an ASEAN country with the highest GDP. In 2002, Indonesia has a GDP of 491.08 million USD, and in 2016 the country has a GDP of 1,03 million USD, an increase of more than $100 \%$ in 14 years. East Timor, the most recent independent country in Southeast Asia, is the country with the lowest GDP among ASEAN members. In 2002, GDP of East Timor is 0.57 million USD and by the end of 2016, East Timor has a GDP of 1.19 million USD. Meanwhile, Myanmar becomes the country with the highest GDP growth within the 14 years. In 2002, Myanmar has a GDP of 19.94 USD, and in 2016 Myanmar's GDP increases by more than double to 74.47 USD.

Most ASEAN countries are endowed with abundant natural resources. Some countries like Indonesia and Brunei Darussalam have abundant petroleum and natural gas resource. Mineral commodities contributions to exports in Indonesia and Brunei Darussalam are above $30 \%$. Singapore, Malaysia, and Vietnam also have substantial contributions of mineral commodities to export, ranging from $10 \%$ to $20 \%$. Aside from mineral resources, most ASEAN countries have abundant agriculture resources, such as Thailand and Vietnam which are main rice exporter countries and Indonesia that depends on the export of forestry commodities. The contributions of agricultural and forestry exports on ASEAN economies are consistently high over time, although not as high as the contribution of mineral resources.

However, the abundance of natural resources cannot lead most ASEAN countries to the level of economic development enjoyed by their ASEAN fellow member such as Singapore, the country that lacks of natural resources. In line with this, Mamun, et al. (2017) highlights the role of quality governance that causes Singapore, Taiwan, Hong Kong, and others who have superior economic growth despite having less natural wealth compared to countries with abundant natural resources. This phenomenon may raise a question of whether the hypothesis of natural resources curse applies to the case of ASEAN countries. Natural resource curse refers to the failure of countries with abundant natural resources to promote their economic development and enhance the welfare of their people (Roberts and Robinson, 2015). The existence of natural resource curse in ASEAN countries is still an important research topic.

The current discourse of economic development in developing countries increasingly takes into account the function of governance. United Nations (UN) defines governance as the practice of political, economic and administrative authority to manage state affairs at all levels. Governance may consist of mechanisms, processes, and institutions through which citizens and their groups carry out their interests, exercise their legal rights, fulfill their obligations and resolve differences between them (UN, 2006).

Government has three related pillars namely economic, political and administrative government. Economic governance includes the decision-making process that facilitates economic activities in a country and interactions between economic actors. Political governance is related to the policy formulation process. While government administration is related to the system of policy implementation. Discourse about the importance of governance is getting stronger in various countries as a response to transform the role of government that is centralized, corrupt, and collusive, towards governance with an orientation of community empowerment in a democratic atmosphere to improve socioeconomic welfare (Rasul, 2009). 
According to World Bank (2018), good governance requires good public sector management (efficient, effective and economic), accountability, free exchange and free access to data (transparency), and a clear legal framework regarding justice and human rights. World Bank publishes one of the most widely used indicator of good governance, Worldwide Governance Indicators (WGIs). WGIs consist of Control of Corruption, Government Effectiveness, Political Stability and Absence of Violence, Regulatory Qualities, Rule of Law, and Voice and Accountability.

Control of Corruption explains the perceptions of the extent to which public power is exercised for personal gain, including petty and grand types of corruption, and the "capture" of the state by elites and vested interest groups. Government effectiveness captures perceptions of public services and civil servants qualities, their degree of independence from political pressure, the quality of policy formulation and implementation, and the commitement of the government to the policies.

Political Stability and Absence of Violence measures perceptions about the possibility of political instability and politically motivated violence, including terrorism. Regulatory Quality explains the perception of the government's ability to formulate and implement good policies and regulations supporting the development of the private sector.

The Rule of Law explains perceptions of government taking responsibility for the community and giving priority to the quality of enforcement of contracts, ownership rights, as well as conflict and violence. The Voice and Accountability captures perceptions about the freedom of society to choose their government, as well as freedom of expression, freedom of association, and freedom of the press.

Good governance has been alleged to play an important role in economic development. The relationship between government and economic growth can be explained through the influence of government qualities that underlies efficiency in managing the public goods supply, the formulation of appropriate policies and regulatory frameworks, and compliance with law (Kim, et al., 2018). Understanding how good governance qualities work to support economic development is of particular interest to both researchers and policymakers.

Given those backgrounds, this research intends to investigate whether natural recourse endowment and good governance play a significant role in post-crisis economic development of ASEAN Countries. Furthermore, extending the existing literature, this research observes the influence of natural resource endowment and good governance in interaction, to accommodate the fact that the effects of natural resource may depend on the specific setting of governance qualities.

Existing studies that investigate the natural resource curse and good governance hypothesis for the case of ASEAN countries are still rare. This study aims to fill this gap. Furthermore, this study also observes the combined effects of natural resource endowment and good governance qualities, instead of only examining those two effects independently. Most existing studies either aggregate or select certain indicators of good governance qualities as indicated by WGIs, on the other hand, this study employs all indicators of WGIs. These approaches enable this study to have more detailed findings and to offer more specific insights into the relationship between natural resource endowment, good governance, and economic growth in ASEAN countries.

This paper is organized as follows. The second section following this introduction is a review of relevant literature and existing empirical studies. The research method is described afterward, followed by a discussion of the empirical results. The conclusion of all findings is presented in the last section.

\section{LITERATURE REVIEW}

Countries with natural resource endowment could use it for the progress of their economies, where the wealth of natural resources may lead to technological and industrial development. Given mineral resource abundance, the United States became a world leader in industrial countries (Wright and Czelusta 2004).

Some European countries are also endowed with natural resources. For instance, Germany has 
an abundant natural resource in the form of coal and nickel, while Scandinavian countries have abundant oil, natural gas, and fisheries. Utilizing their natural resources, those countries have developed advanced economies. However, those success stories do not apply to most countries in Africa, Latin America, and Asia. A study from Akylbekova (2015) compares countries with abundant natural resources and countries with lack of natural resources. The study confirms the phenomenon that abundant natural resources countries such as Nigeria, Congo, Venezuela and others face problems of low economic growth and living standards, while several Asian countries with less natural resources such as Korea, Hong Kong, Singapore and Taiwan experience high economic growth.

Oyinlola, Adeniyi, and Raheem (2015) argue that national income in the countries without abundant natural resources are twice (or more) as high as those in natural resources abundant countries. In accordance with that finding, the study of Mamun, et al. (2017) also finds that Singapore, Taiwan, Hong Kong, and other countries with limited natural wealth but better governance are having relatively superior economic growth than Libya and Iran that benefit from abundant natural resources. Mamun, et al. (2017) conclude by supporting the importance of governance qualities in economic growth.

According to Roberts and Robinson (2015), natural resource curse, or commonly known as the paradox of plenty, refers to the failure of many countries with resource abundance to get the full benefit of their natural resource wealth, and the failure of the governments in these countries to respond effectively to the needs of public welfare. While it is expected to have better economic development outcomes after countries discover abundant natural resources, resource rich countries tend to have higher levels of conflict and authoritarianism, and lower levels of economic stability and economic growth.

Sach and Warner (1995) are among the first to explain the effects of natural resource abundance on the economies. They argue that natural resource abundance often leads to greater corruption and inefficient bureaucracy. Due to that governance problems, countries with abundant natural resources experienced slower economic growth than their counterparts. Natural resource abundance does not provide incentives for the government to improve the performance of other economic sectors. Abundance of natural resources also creates inequality in society due to mismanagement of income and corruption. Therefore, natural resource abundance eventually becomes one of the reasons for poor economic performance in developing countries.

Supporting the argument of Sachs and Warner (1995), the study of Bakwena, et al. (2009) find that the qualities of governance have a positive and significant effect on economic growth. They also examine the interaction effects of natural resources and the qualities of governance on economic growth and find significant impacts.

According to Alayli and Karp (2005), the failure of abundant natural resources countries to utlize their resources for improving their economic development is due to the weak governance, particularly in relation to the failure of democracy and accountability. In line with this argument, Fearon (2014) states that the wealth of natural resources also contributed to civil society conflicts that could lead to domestic instability.

Furthermore, the wealth of natural resources also fails to provide incentives for governments to develop other economic sectors, and ultimately becomes one of the reasons for poor economic performance. At the same time, the abundance of natural resources may create inequality in society, caused by mismanagement of income and corruption, and thus becomes dangerous for the economy (Zagozina, 2014). Zagozina crosscountries study (2014) also show that renewable natural resource variables have a positive and significant effect on economic growth when there are good institutions in the respective countries. These result is in line with the conclusion of qualitative study of Kolstad and Wiig (2009) that good Institutional quality can suppress problems arising from the abundance of natural resources. Zagozina (2014) finds that the difference of natural resources will affect the pattern of production and income distribution. Oil and minerals lead to more concentrated production and income patterns, while production and income generated by agriculture and forestry resources are more spread 
throughout the economy. Consequently, abundant endowments of agriculture and forestry sectors have more desirable effects on the economies. Furthermore, Zagozina (2014) argues that high dependence on export of natural resource is dangerous for a country, especially with low governance qualities

Regarding the importance of good governance, a study of Kraipornsak (2018) analyzes the effect of good governance on economic growth as indicated by on income per capita in the selected 16 Asian countries. The result shows that good governance is a significant factor that contributes to income per capita growth. Mauro (1995) using cross-country research finds that corruption has a negative impact on investment and economic growth. This finding is also echoed by more recent research of Svensson (2005) that concludes corruption has a negative impact on economic growth. Farooq, et al. (2013) also find the existence of a detrimental impact of corruption on economic growth in Pakistan. They imply that the government must take measures to reduce the level of corruption by improving governance in the country. Improved governance will not only mitigate the corruption incidences but also improve the quality of domestic institutions, which results in accelerated economic growth.

Previous studies show that economic growth and political stability are two closely related variables. For example, a study from Alesina et al. (2016) indicates that political instability has a negative relationship with a country's economic growth. Uncertainty associated with an unstable political environment can reduce investment and the pace of economic development. Koeniger and Silberberger (2013) find a positive effect of the quality of rules and policies on economic growth. The government's ability to formulate and implement good policies and regulations will enable and encourage the development of the private sector which leads to economic growth. The effect of rule of law has also been investigated. Haggard and Tiede (2011) argue that one of the factors affecting economy in the long run is the role of institutions and legal certainty especially protection of copyright.

\section{RESEARCH METHOD}

This study observes economic development in ASEAN countries as a function of natural resource endowment, good governance, and the interaction between natural resource endowment and good governance. This study uses the data of 11 ASEAN countries including Indonesia, Malaysia, Singapore, Thailand, Philippines, Vietnam, Laos, Myanmar, Cambodia, Brunei Darussalam, and East Timor, during the period of 2002 to 2016.

In this study, economic development as the dependent variable is approached by Gross Domestic Product (GDP) with constant price 2010 in US dollars. This study includes two types of natural resource endowment, non-renewable and renewable natural resources, as independent variables. Non-renewable natural resource refers to mineral resources, measured by the contribution of the mineral sector exports in GDP. While renewable resource refers to agriculture resource, approached by the contribution of agricultural sector exports in GDP.

Most existing studies that include good governance as independent variable are either aggregating the good governance indicators presented by World Governance Index (WGI) into one single category or using a few selected WGI categories. However, this study uses all six indicators of WGI to have more detailed observation with regard to which governance qualities are significant for the ASEAN economies. Those six indicators are Control of Corruption, Government Effectiveness, Political Stability and Absence of Violence, Regulatory Qualities, Rule of Law, and Voice and Accountability. Equation 1 below presents the estimation model in this study. Interacting variables are indicated by the asterisk sign $(*)$. For example, the interaction of agriculture resources and control of corruption is depicted by $\mathrm{AGR} * \mathrm{CC}$. 


$$
\begin{aligned}
& G D P_{i, t}=\beta_{1} G D P_{i, t-1}+\beta_{1} Y_{i, t-1}+ \\
& \beta_{2} A G R_{i, t}+\beta_{3} M I N_{i, t}+\beta_{4} C C_{i, t}+\beta_{5} G E_{i, t}+ \\
& \beta_{6} P S_{i, t}+\beta_{7} R Q_{i, t}+\beta_{8} R L_{i, t}+\beta_{9} V A_{i, t}+ \\
& \beta_{10}\left(A G R_{i, t} * C C_{i, t}\right)+\beta_{11}\left(A G R * G E_{i, t}\right)+ \\
& \beta_{12}\left(A G R * P S_{i, t}\right)+\beta_{13}\left(A G R * R Q_{i, t}\right)+ \\
& \beta_{14}\left(A G R * R L_{i, t}\right)+\beta_{15}\left(A G R * V A_{i, t}\right)+ \\
& \beta_{16}\left(M I N * C C_{i, t}\right)+\beta_{17}\left(M I N * G E_{i, t}\right)+ \\
& \beta_{18}\left(M I N * P S_{i, t}\right)+\beta_{19}\left(M I N * R Q_{i, t}\right)+ \\
& \beta_{20}\left(M I N * R L_{i, t}\right)+\beta_{21}\left(M I N * V A_{i, t}\right)+ \\
& \mathrm{v}_{\mathrm{i}}+e_{i, t}
\end{aligned}
$$

$\begin{array}{ll}\text { GDP } & \text { : Gross Domestic Product } \\ \text { AGR } & \text { : Agriculture Resources } \\ \text { MIN } & \text { : Mineral Resources } \\ \text { CC } & \text { : Corruption Control } \\ \text { GE } & \text { : Government Effectiveness } \\ \text { RQ } & \text { : Regulatory Qualities } \\ \text { RL } & \text { : Rule of Law } \\ \text { VA } \quad \text { : Voice and Accountability } \\ \text { PS : Political Stability and Absence of } \\ \text { Violence }\end{array}$

This study applies panel data analysis. The use of panel data offers several advantages over other data models. The combination of time series and cross section data enable panel data to provide more informative and varied estimates, a higher degree of freedom, and more efficient models (Baltagi, 2008). More specifically, this study uses dynamic panel data analysis, in particular Generalized Method of Moment (GMM) system method. Hsiao (2004) describes dynamic panel data as a model that accommodates the dynamic relationships of the data. The dynamic relationship is shown by the inclusion of lag in the dependent variable among independent variables. The advantage of using GMM system method is its ability to address the classical assumption problems that arise in testing static panel data (Roodman, 2009) and to accommodate lags as determinants that affect the dependent variable.

\begin{tabular}{|c|c|c|c|c|c|c|c|c|c|c|c|c|}
\hline \multicolumn{2}{|c|}{ WGIs } & \multirow{2}{*}{$\begin{array}{c}\text { IDN } \\
-1.14\end{array}$} & \multirow{2}{*}{$\begin{array}{l}\text { MYS } \\
0.27 \\
\end{array}$} & \multirow{2}{*}{$\begin{array}{l}\text { SGP } \\
2.32\end{array}$} & \multirow{2}{*}{$\begin{array}{l}\text { THA } \\
-0.31\end{array}$} & \multirow{2}{*}{$\begin{array}{l}\text { PHL } \\
-0.5\end{array}$} & \multirow{2}{*}{$\begin{array}{l}\text { VNM } \\
-0.57\end{array}$} & \multirow{2}{*}{$\begin{array}{l}\text { LAO } \\
-1.15\end{array}$} & \multirow{2}{*}{$\begin{array}{l}\text { MMR } \\
-1.32 \\
\end{array}$} & \multirow{2}{*}{$\begin{array}{l}\text { KHM } \\
-1.01\end{array}$} & \multirow{2}{*}{$\begin{array}{l}\text { BRN } \\
0.31\end{array}$} & \multirow{2}{*}{$\begin{array}{c}\text { TML } \\
-0.21\end{array}$} \\
\hline $\mathrm{CC}$ & 2002 & & & & & & & & & & & \\
\hline & 2016 & -0.39 & 0.11 & 2.07 & -0.4 & -0.53 & -0.4 & -0.93 & -0.65 & -1.3 & 0.66 & -0.51 \\
\hline \multirow[t]{2}{*}{ GE } & 2002 & -0.41 & 1.02 & 1.85 & 0.31 & -0.13 & -0.44 & -0.91 & -1.31 & -0.81 & 0.89 & -0.73 \\
\hline & 2016 & 0.01 & 0.88 & 2.21 & 0.34 & -0.01 & 0.01 & -0.29 & -0.98 & -0.69 & 1.07 & -1.03 \\
\hline \multirow[t]{2}{*}{ PS } & 2002 & -1.58 & 0.54 & 1.26 & 0.51 & -0.86 & 0.35 & -0.1 & -1.41 & -0.73 & 1.16 & -0.49 \\
\hline & 2016 & -0.38 & 0.1 & 1.53 & -0.93 & -1.3 & 0.17 & 0.5 & -0.63 & 0.18 & 1.26 & -0.08 \\
\hline \multirow[t]{2}{*}{$\mathrm{RQ}$} & 2002 & -0.64 & 0.56 & 1.94 & 0.18 & -0.1 & -0.72 & -1.3 & -2.06 & -0.31 & 1.09 & -1.22 \\
\hline & 2016 & -0.12 & 0.71 & 2.18 & 0.17 & 0 & -0.45 & -0.73 & -0.87 & -0.47 & 0.59 & -0.98 \\
\hline \multirow[t]{2}{*}{$\mathrm{RL}$} & 2002 & -0.91 & 0.45 & 1.41 & 0.38 & -0.37 & -0.64 & -1.15 & -1.71 & -1.14 & 0.5 & -0.83 \\
\hline & 2016 & -0.36 & 0.54 & 1.83 & 0.01 & -0.4 & 0.05 & -0.77 & -0.99 & -1.1 & 0.62 & -1.2 \\
\hline \multirow[t]{2}{*}{ VA } & 2002 & -0.27 & -0.49 & 0.06 & 0.32 & 0.16 & -1.45 & -1.74 & -2.01 & -0.74 & -0.83 & 0.27 \\
\hline & 2016 & 0.14 & -0.47 & -0.28 & -1.1 & 0.14 & -1.41 & -1.73 & -0.85 & -1.14 & -0.95 & 0.24 \\
\hline
\end{tabular}

\section{RESULTS AND DISCUSSION}

Before the presentation of econometrics analysis results, this paper will first describe the good governance indicators of ASEAN Countries as indicated by the WGI components. Table 1 displays the value of each WGI component in ASEAN Countries in 2002 and 2016.

Table 1: The Values of WGI Components in ASEAN Countries (2001 and 2016) 


$\begin{array}{lll}\text { Notes: } & \text { IDN } & : \text { Indonesia } \\ \text { MYS } & : \text { Malaysia } \\ \text { SGP } & : \text { Singapore } \\ \text { THA } & : \text { Thailand } \\ \text { PHL } & : \text { Philippines } \\ \text { TML } & : \text { Timor Leste } \\ \text { VNM } & : \text { Vietnam } \\ \text { LAO } & : \text { Laos } \\ \text { MMR } & : \text { Myanmar } \\ \text { KHM } & : \text { Cambodia } \\ \text { BRN } & : \text { Brunei Darussalam }\end{array}$

In Table 1, there are only three countries whose values of Control of Corruption is positive at the end of 2016; Singapore, Malaysia and Brunei Darussalam. In the period 2002 to 2016, the country that had the best Control of Corruption was Singapore. The other countries have experienced various trends in terms of control of corruption. Indonesia, Malaysia, Vietnam, Laos, and Myanmar improve their Control of Corruption over time, while Thailand, the Philippines, Cambodia, Brunei, and Timor Leste experiences a decline in corruption control.

Singapore boasts the best value for Government Effectiveness, while Timor Leste suffers the worst value of that indicator from 2002 to 2016. However, all ASEAN Countries experiences improvements in Government Effectiveness over time. Countries such as Indonesia and Vietnam are able to improve the quality of their governance, previously categorized as bad performance in 2002 to be a good performance in 2016. Singapore is perceived as the country with the best value in terms of Political Stability, followed by Brunei, Laos, Cambodia, Vietnam, and Malaysia.

ASEAN countries (excluding Cambodia and Brunei) experience improvements in Regulatory Quality. There are five countries categorized as good performing countries in this category at the end of 2016; Singapore holds the best value, followed by Malaysia, Brunei, Thailand, and the Philippines. Singapore is still the country with the best value in the category of Rule of Law. Other ASEAN countries categorized as good performing countries in this category are Malaysia, Singapore,
Thailand, Vietnam, and Brunei. However, Singapore suffers bad performance in the category of Voice and Accountability at the end of 2016, joining ASEAN Countries with authoritarian governments such as Vietnam, Laos, Myanmar, and Brunei. The good performing countries in this category at the end of 2016 are Indonesia, the Philippines, and Timor Leste.

After briefly presenting the good governance indicators as indicated by WGI components, this paper proceeds to explain the results of econometrics analysis. The effect of natural resource, governance qualities, and the combined effect of those two on GDP of ASEAN countries are examined using GMM method. The GMM method is designed for models with large number of observations and short time series range, and may answer the problem of autocorrelation and heterocedasticity in the panel data (Roodman, 2009). The estimation results are presented in Table 2.

Table 2: GMM System Estimation Results

\begin{tabular}{|c|c|c|c|}
\hline Variables & Coefficients & z statistics & p-values \\
\hline $\mathrm{Y}(\mathrm{t}-1)$ & 1.042039 & 287.64 & 0.000 \\
\hline $\mathrm{CC}$ & 8037.519 & 2.89 & $0.004^{*}$ \\
\hline GE & -524.9704 & -0.11 & 0.913 \\
\hline PS & 2526.12 & 3.36 & $0.001^{*}$ \\
\hline$R Q$ & -8235.418 & -1.44 & 0.151 \\
\hline $\mathrm{RL}$ & -3607.609 & -0.40 & 0.691 \\
\hline VA & 5586.348 & 3.88 & $0.000^{*}$ \\
\hline MNR & 18435.8 & 0.98 & 0.327 \\
\hline AGR & -65752.79 & -1.39 & 0.165 \\
\hline $\mathrm{MNR}^{*} \mathrm{CC}$ & -11969.65 & -1.15 & 0.250 \\
\hline $\mathrm{MNR}^{*} \mathrm{GE}$ & 2053.834 & 0.25 & 0.803 \\
\hline MNR*PS & -9435.71 & -1.05 & 0.294 \\
\hline$M N R^{*} R Q$ & 23131.9 & 1.47 & 0.142 \\
\hline$M N R^{*} \mathrm{RL}$ & -12381.82 & -0.67 & 0.503 \\
\hline $\mathrm{MNR}^{*} \mathrm{VA}$ & -340.5483 & -0.03 & 0.979 \\
\hline $\mathrm{AGR}^{*} \mathrm{CC}$ & -53219.94 & -2.71 & $0.007^{*}$ \\
\hline$A G R^{*} G E$ & 89683.74 & 3.18 & $0.001^{*}$ \\
\hline$A G R * P S$ & 49635.5 & 3.03 & $0.002^{*}$ \\
\hline$A G R * R Q$ & -67537.49 & -1.82 & 0.069 \\
\hline$A G R * R L$ & -3446.42 & -0.08 & 0.938 \\
\hline$A G R * V A$ & 21294.79 & 1.17 & 0.240 \\
\hline AR (2) & -2478.46 & -0.48 & 0.631 \\
\hline
\end{tabular}


The estimation results show that GDP in the previous period, GDP ( $\mathrm{t}-1)$, has a positive and statistically significant effect on the current GDP. Three out of six indicators of good governance significantly affect GDP in ASEAN countries. Those indicators are Political Stability (PS), Voice and Accountability (VA), and Control of Corruption (CC). Political Stability has a positive impact on GDP and statistically significant at 5\% significance level. Political Stability measures the perceived possibility of political instability and politically motivated violence, which include terrorism. This study finds that a stable political situation is associated with the increase of GDP in ASEAN countries. Economic activities will run smoothly in the absence of political chaos, when political situation in particular country is stable and free of turmoil. Terrorism is another aspect that features the political stability. When terrorism incidents occur frequently in certain countries, investors will withdraw their capital and move it to the more stable countries. In general, political instability will lead to capital outflows and the decline in domestic economic activities that eventually hampers GDP in the respective countries.

Variable of Voice and Accountability, which is measured by the perception of the extent to which citizens can participate in choosing their government, as well as freedom of expression, freedom of association, and freedom of the press, has a positive effect on GDP of ASEAN countries and statistically significant at 5\% significance level. The presence of democratic regimes that encourage freedom of opinion and economic creativity may lead to better performing economies in ASEAN. Democratic regimes that demand transparency supported with press freedom are associated with active public supervision and monitoring, and it will provide the incentive for the government as well as private sectors to work optimally.

Supporting the argument regarding the importance of corruption issues in economic development, this study finds that Control of Corruption has positive effect on GDP and it is statistically significant at 5\% level of significance. Control of Corruption demonstrates the perceptions of the extent to which public power is abused for personal gain, including small and large forms of corruption, as well as capture by the elites and personal vested interests. The value of control of corruption in ASEAN countries has been improving during years of observation, in line with the increase in GDP of ASEAN countries.

Mineral and agricultural variables do not have significant effects on GDP. These findings are contradicting the study results of Zagozina (2014). In the case of Ex-Soviet Union, Zagozina (2014) finds that the countries with higher dependence on mineral resource experience a slower economic growth, while those with dependence on agriculture export are able to develop a better economy. That conclusion apparently does not apply to the case of ASEAN countries.

In this study, the insignificance of natural resource endowment applies to the case in which we separate the effect of natural resource endowment and governance qualities. However, natural resource curse is often found in the economies with bad qualities of governance (among others, Sachs and Warner, 1995; Bakwena, et al., 2009; Zagozina, 2014). Therefore, examining the effect of natural resource abundance in interaction with the governance qualities seems imperative.

The results of econometric analysis show that the interaction variables between mineral with Regulatory Quality (MNR * RQ) has positive effect on GDP, and statistically significant at 5\% significance level. Regulatory Quality indicator captures the perception of the government's ability to formulate and implement good policies and regulations. When the governments are able to create good quality regulations, dominant mineral resources export can stimulate economic activities in the economies that lead to higher GDP per capita. The interaction variable between agriculture and Government Effectiveness $\left(\mathrm{AGR}^{*} \mathrm{GE}\right)$, interaction variable between agriculture and Political Stability (AGR*PS), as well as interaction variable between agriculture and Voice and Accountability (AGR*VA) have significantly positive effects on GDP. Government Effectiveness explains the perception on the quality of public services, the quality of civil servants and the level of independence from 
political pressure, the quality of the formulation and implementation of policies, and the credibility of the government's commitment to the policy. Higher domination of agriculture export in GDP in the ASEAN economies with better performance of Governance Effectiveness is associated with higher GDP. Higher contribution of agriculture export on GDP in the ASEAN economies with better performance of Political Stability and better Voice and Accountability are also associated with higher GDP.

The interaction between agriculture and Control of Corruption is the only significant interaction variable that has a negative influence on GDP, meaning that the increase of agriculture export contribution in GDP given the current situation of corruption control in ASEAN countries will be associated with a decrease of GDP. This result is interesting because the Control of Corruption has a positive effect on GDP when it is observed in isolation. The contrasting result can be explained by the fact that although there is an improvement of corruption control over time; the progress is still within poor performance category (as indicated by the fact that most ASEAN countries still suffers the negative values of Control of Corruption). Thus, the dependence on agriculture resources as the main exported commodities within economies that are still characterized by bad performance of corruption control will lead to worsening GDP.

\section{CONCLUSION AND RECOMMENDATION}

This study finds that governance qualities play a significant role in the ASEAN economies after the great financial crisis in 1998. Out of six governance indicators, Political Stability, Control of Corruption, and Voice and Accountability are significantly affecting the GDP. The increase in the quality of those indicators is associated with higher GDP among ASEAN members. Thus, a good governance hypothesis that postulates good governance practices will improve economic development is to some extent confirmed.

The observation of the existence of natural resource curse in ASEAN countries returns mixed results. The dependence on natural resource, as indicated by the contribution of agriculture and mineral resource export on the GDP, by itself do not show significant influence on the GDP. The natural resource curse exists when the countries rely on the agriculture sector export while Control of Corruption is still under bad performance category. However, the natural resource becomes a blessing when the countries that rely on agriculture sector export are supported with good Government Effectiveness and robust Voice and Accountability. These findings support the argument that the effect of natural resources on economic development in particular country will depend on the governance performance of the respective country.

In general, the findings of this study confirm the importance of good governance practices. In particular, ASEAN countries still have to improve the quality of corruption control, so that the potential of natural resource curse can be reversed into natural resource blessing.

\section{REFERENCES}

Akylbekova, D. (2015). Analyzing the Resource Curse Theory : a Comparative Study of Kazahstan and Norway. Thesis.

Alesina, A., Ozler, S., Roubini, N., and Swagel, P. (2016). Political Instability and Economic Growth. National Bureau of Economic Research, 13 (2), 443-453.

Bakwena, M., Bodman, P., Le, T., \& Tang, K. K. (2009). Avoiding the Resource Curse : The Role of Institutions. MRG Discussion Paper Series, 32, 1-33.

Baltagi, B. H. (2008). Econometrics (4th Edition). New York: Springer-Verlag Berlin Heidelberg.

Farooq, A., Shahbaz, M., Arouri, M., \& Teulon, F. (2013). Does Corruption Impede Economic Growth in Pakistan? Economic Modelling,35, 622-633.

Haggard, S, and Tiede, L. (2011) The Rule of Law and Economic Growth: Where Are We? World Development, 39 (5), 673-685.

Hsiao, C. (2004). Analysis of Panel Data (2nd Edition). Cambridge: Cambridge University Press. 
Huang, C. J., \& Ho, Y. H. (2017). Governance and Economic Growth in Asia. North American Journal of Economics and Finance, 39(100), 260-272.

Kim, Dong Hyeon, Yi Chen Wu, and Shu Chin Lin. 2018. "Heterogeneity in the Effects of Government Size and Governance on Economic Growth." Economic Modelling, 68, 205-216.

Koeniger, J, and Silberberger, M. (2013). Regulation, Trade and Economic Growth. Center for European Governance and Economic Development Research, 255, 594-621.

Kolstad, Ivar, and Arne Wiig. 2009. "Political Economy Models of the Resource Curse : Implications for Policy and Research." Working Paper - Chr. Michelsen Institute, no. 40, 1-20.

Kraipornsak, P. (2018). Good Governance and Economic Growth: An Investigation of Thailand and Selected Asian Countries. Eurasian Journal of Economics and Finance, 6, 93-106.

Mamun, Md Al, Kazi Sohag, and M. Kabir Hassan. 2017. "Governance, Resources and Growth." Economic Modelling, 63, $238-261$.

Mauro, P. (1995). Corruption and Growth. The Quartlerly Journal of Economics, 110(3), 681-712.

Oyinlola, M. A., Adeniyi, O. A., \& Raheem, I. D. (2015). Natural Resource Abundance, Institutions and Economic Growth in Africa. African Journal of Economic and Sustainable Development, 4(1), 34.
Rasul, Sjahruddin. 2009. "Penerapan Good Governance Di Indonesia Dalam Upaya Pencegahan Tindak Pidana Korupsi." Mimbar Hukum 21 (3), 538-553.

Roberts, J. M., \& Robinson, J. A. (2015). The Resource Curse - The Political and Economic Challenges of Natural Resource Wealth. NRGI Reader, (March), 71-78.

Roodman, D. (2009). How to Do xtabond2: An Introduction to Difference and System GMM in Stata. Stata Journal, 9(1), 86-136.

Sachs, J. D., \& Warner, A. M. (1995). Natural Resource Abundance and Economic Growth. NBER Working Paper Series, 3, 54.

Svensson, J. (2005). Eight Questions about Corruption. Journal of Economic Perspectives, 19 (3), 19-42.

United Nations. 2006. Definition of Basic Concepts and Terminologies in Governance and Public Administration. Uniterd Nations.

World Bank (2018). Worldwide Governance Indicator. Available at https://info. worldbank.org/governance/wgi/\#home [Retrieved at September 10, 2019]

Wright, G., \& Czelusta, J. (2004). The Myth of the Resource Curse. Challenge, 47(2), 6-38.

Yousefi, A. (2011). The Impact of Information and Communication Technology on Economic Growth: Evidence from Developed and Developing Countries. Economics of Innovation and New Technology, 20(6), 581-596.

Zagozina, M. (2014). The Resource Curse Paradox: Natural Resources and Economic Development in The Former Soviet Countries, Thesis, 1-70. 